\title{
Economic Rights and Regional Integration: Considering the EU and ASEAN Charters within the Perspective of Global Regional Integration
}

\author{
Ali M. El-Agraa \\ Fukuoka University
}

\begin{abstract}
The paper is confined to addressing the question of whether a relationship exists between 'economic rights' and 'regional integration'; confined because the title has several manifestations and interpretations. I categorically assert that there is not: regional integration is governed by WTO's Article XXIV, which is utterly silent on 'economic rights', or for that matter 'human rights'; human rights being the basic rights to which all humans are entitled, often held to include the right to life and liberty, freedom of thought and expression, and equality before the law. I find that the EU is the only regional integration scheme that has been endeavouring to give economic rights a legally-binding basis, but this will not happen fully even when the Lisbon Treaty has been ratified, due to the enactment not being embracive since Poland and the UK have opt-out protocols; thus rendering the term regional integration somewhat meaningless within this context. This, however should not distract from the fact that the EU has been able to make progress with and achieve the promotion of human rights in areas where single member state efforts have been to no avail; feats that would otherwise not have been possible without the creation of a single European state. The implications of this for the yet-to-be-ratified ASEAN Charter are briefly tackled where they are pertinent within the EU context.
\end{abstract}

- JEL Classification: F13, F15, I00, P00, Z00

- Key Words: regional integration, human rights, economic rights, WTO rules

\footnotetext{
*Ali M. El-Agraa: Faculty of Commerce, Fukuoka University, 8-19-1 Nanakuma, Jonan-ku, Fukuoka 814-0180, Japan, Tel: 81-92-871-6631, Fax: 81-92-864-2938, e-mail: elagraa@fukuoka-u.ac.jp.

(C)2009-Center for International Economics, Sejong Institution, Sejong University, All Rights Reserved.
} 


\section{Introduction}

There have recently been claims that 'regional integration' and the promotion of 'human rights' are intertwined. This has been the case even before the proclamation by the European Union (EU) in 2000 of its Charter of Fundamental Rights of the European Union ${ }^{1}$; hence well in advance of the adoption in 2007 by the Association of South East Asian Nations (ASEAN) of its Charter of the Association of South East Asian Nations ${ }^{2}$, in which they are categorically specified. Since the EU and ASEAN seem not only to be in the same boat on this issue, but also that ASEAN is essentially emulating the EU in this regard and generally, the aim of this paper is tackle this subject with this perspective in mind. However, because both associations are regional integration schemes, in which practically every country in the world participates ${ }^{3}$, it seems more appropriate to have the wider perspective by discussing human rights within the global context of regional integration.

The paper begins by setting the scene by providing a justification for why the discussion is limited to only 'economic rights'. It goes on to consider the legal framework under which regional integration operates, proceeds to human rights and their affinity or otherwise to regional integration. The paper finishes by explaining why the EU is unique when it comes to economic and human rights and by providing instances that show where the EU has succeeded when all efforts at the national level had been to no avail.

\section{Setting the Scene}

'Human rights and regional integration' is a very wide-ranging subject. It could be about the mere existence of a relationship between 'human rights' and 'regional integration' such that the rules of the game dictate that they should go hand in hand; hence the concern would be about whether or not regional integration schemes have been complying with the legal requirements for human rights. It could also be about whether or not existing schemes of regional integration have voluntarily been incorporating human rights into their treaties, in which case we

\footnotetext{
${ }^{1}$ European Commission (2000) and European Commission (2007a). For the version adapted in the light of the Lisbon Treaty on 3 December, European Commission (2007b).

${ }^{2}$ Singed on 20 November 2007; see, Association of South East Asian Nations (2007b).

${ }^{3}$ See El-Agraa (2007) for these.
} 
would be concerned with an examination of all such schemes with this perspective in mind. It could moreover be about whether or not regional integration should promote human rights, inviting a theoretical discussion of the pros and cons. It could further be about inciting an open-ended discussion and reflections on whether or not any relationship at all should exist between them or whether or not they should be intertwined. The mind boggles.

Given space limitations, I cannot tackle all these manifestations in a single paper. Moreover, the content will have to be greatly diluted if I were to consider all human rights; human rights being 'the basic rights to which all humans are entitled, often held to include the right to life and liberty, freedom of thought and expression, and equality before the law'. ${ }^{4}$ I shall therefore concentrate on only the 'economic rights', although what I have to say would apply to several items in the human rights' list. Confining myself to whether or not a relationship exists between these two, I categorically assert that there is not: regional integration has nothing whatsoever to do with 'economic rights' or for that matter human rights. I shall therefore confine my discussion to justifying this assertion.

\section{Regional Integration and Economic Rights}

\section{A. Regional Integration}

Regional integration is governed by Article XXIV of the General Agreement on Tariffs and Trade (GATT) and since 1994 of its successor, the World Trade Organisation (WTO). ${ }^{5}$ The Article however deals with only 'free trade areas' (FTAs), now rightly termed 'preferential trading agreements/arrangements' (PTAs), and 'customs unions' (CUs). It is silent on 'common markets' (CMs)' and 'economic unions' (EcUs), not to mention 'economic partnership agreements' (EPAs) and some would even add complete political integration' ${ }^{6}$, i.e. the German unification in 1990. Moreover, the Article simply states the conditions under which PTAs and CUs would be condoned and these relate merely to: (a) the removal of restrictions on intra-partner trade (that tariffs and other trade restrictions, with some exceptions, are removed on substantially - increasingly interpreted to mean at least $90 \%$ of - all the trade amongst the participating nations); and (b) the level of

\footnotetext{
${ }^{4}$ See, Pickett (2000).

${ }^{5}$ See Appendix 1 for the full text of Article XXIV.

${ }^{6}$ For a definition of schemes of regional integration, see, inter alia, El-Agraa $(2007,1999,1998,1982)$ and El-Agraa and Jones (1982).
} 
protection against the non-members (that the participating countries may not pursue policies which increase the level of their discrimination beyond that which existed prior to their formation). ${ }^{7}$ In other words, nowhere in Article XXIV is there a mention of economic rights or human rights.

\section{B. Human Rights and Economic Rights}

Human rights are generally the concern of the United Nations (UN) which passed its resolution on them in $1948^{8}$, the United Nations Universal Declaration of Human Rights (hereafter, simply Universal Declaration). The Universal Declaration tells us that 'All human beings are born free and equal in dignity and rights. They are endowed with reason and conscience and should act towards one another in a spirit of brotherhood'. The UN is the only international body with jurisdiction for human rights legislation. The United Nations Human Rights Council is involved with the investigation into violations of human rights and the International Court of Justice (ICJ) is the UN's principal judicial organ.

The Universal Declaration includes a short but substantial list of rights that has been further elaborated, with modest additions, in a variety of later treaties, most notably the 1966 International Human Rights Covenants ${ }^{9}$ : The United Nations International Covenant on Civil and Political Rights ${ }^{10}$; and the International Covenant on Economic, Social and Cultural Rights ${ }^{11}$; the latter being my main concern. ${ }^{12} \mathrm{~A}$ full list of the items in all three documents is provided in Table 1 and those in italics are, directly or indirectly, the concern of this paper since they are devoted to work, trade unionism, property ownership, social security, standard of living (25), education (26) and the like. ${ }^{13}$

Human rights are also the concern of the Council of Europe, coming under the Convention for the Protection of Human Rights and Fundamental Freedoms,

\footnotetext{
${ }^{7}$ See, inter alia, El-Agraa $(2007,1982)$.

${ }^{8}$ Adopted by the UN General Assembly resolution 217 A(III) on 10 December 1948. http:// www.unhchr.ch/html/menu6/2/fs2.htm

${ }^{9}$ See Donnelly (2003, p. 3) for a fuller exposition.

${ }^{10}$ See United Nations (1966a).

${ }^{11}$ See United Nations (1966b).

${ }^{12}$ The Universal Declaration and the two Covenants provide the norms of what is referred to as 'the global human rights regime', a system of rules and implementation procedures centered on the UN. Its principal organs are the UN Commission on Human Rights, the Human Rights Committee and the High Commissioner for Human Rights. See, Donnelly (2003, p. 129). For an excellent exposition of the relationship between the Universal Declaration and the two Covenants, see Whelan and Donnelly (2007), who argue that the Covenants came about as a result of the need to give the rights in the Universal Declaration a binding force in international law (p. 927).
} 
Table 1. Subtance of the Universal Declaration Model

\begin{tabular}{|c|c|}
\hline Nondiscrimination (UD2, E2, C2) & Paricipation in government (UD21, C25) \\
\hline Life (UD3, C6) & Social security (UD22, E9) \\
\hline Liberty and security of person (UD3, C9) & Work (UD23, E6) \\
\hline Protection against slavery (UD4, C8) & $\begin{array}{l}\text { Just and favourable conditions of work } \\
\text { (UD23, E7) }\end{array}$ \\
\hline Protection against torture (UD5, C7) & Trade unions (UD23, E8, C22) \\
\hline Legal personality (UD6, C16) & Rest and leisure (UD24, E7) \\
\hline Equal protection of the law (UD7, C14, C26) & Adequate standard of living (UD25, E11 \\
\hline Legal remedy (UD8, C2) & Education (UD26, E13) \\
\hline $\begin{array}{l}\text { Protection against arbitrary arrest, detention or } \\
\text { exile (UD9, C9 }\end{array}$ & Participation in cultural life (UD27, E15) \\
\hline $\begin{array}{l}\text { Access to indepenedent and impartial tribunal } \\
\text { (UD10, C14) }\end{array}$ & Self-determination (E1, C1) \\
\hline Presumption of innocence (UD11, C14) & $\begin{array}{l}\text { Protection of and assistance to children } \\
(\mathrm{E} 10, \mathrm{C} 24)\end{array}$ \\
\hline Protection against ex post facto laws(UD11, C15) & Freedon from hunger (E11) \\
\hline Privacy (UD12, C17) & Health (UD25, E12) \\
\hline Freedom of movement (UD13, C12) & Asylum (UD14) \\
\hline Nationality (UD15, C24) & Property (UD17) \\
\hline Marry and found a family (UD16, C23) & Compulsory primary education (E14) \\
\hline $\begin{array}{l}\text { Protection and assistance of families } \\
\text { (UD16, E10, C23 }\end{array}$ & $\begin{array}{l}\text { Humane treatment when deprived of liberty } \\
\text { (C10) }\end{array}$ \\
\hline $\begin{array}{l}\text { Marriage only with free consent of spouses } \\
\text { (UD16, E10, C23) }\end{array}$ & $\begin{array}{l}\text { Protection agianst imprisonment for a debt } \\
\text { (C11) }\end{array}$ \\
\hline $\begin{array}{l}\text { Equal rights of men and women in marriage } \\
\text { (UD16, C23) }\end{array}$ & Expulsion of aliens only by law (C13) \\
\hline $\begin{array}{l}\text { Freedom of thought, conscience and religion } \\
\text { (UD18, C18) }\end{array}$ & $\begin{array}{l}\text { Prohibition of war propaganda and incite- } \\
\text { ment to discrimnation (C20) }\end{array}$ \\
\hline Freedom of opinion and expression (UD19, C19) & Minority culture (C27 \\
\hline \multicolumn{2}{|c|}{ Freedom of assembly (UD20, C21) } \\
\hline Freedom of association (UD20, C22) & \\
\hline
\end{tabular}

Notes: 1. UD stands for the Universal Declaration; C for the Interntional Covenant on Civil and Political Rights; and E for the Interntaional Convention on Economic, Social and Cultural Rights. 2. The figures refer to articles numbers.Source: slightly adpated from Donnelly (2003), p. 24

\footnotetext{
${ }^{13}$ The list of human rights is generally simplified by classifying the various items into six categories: (a) Security Rights which prohibit crimes (e.g. murder), enforced involuntary suicide, massacre, torture and rape; (b) Liberty Rights which protect freedoms with regard to, for example, belief, religion, association, assembling and movement; (c) Political Rights which protect against abuses of the legal system, for example, arrest and imprisonment without trial, secret trials and excessive punishments; (d) Equality Rights which guarantee equal citizenship, equality before the law and non-discrimination; (e) Welfare Rights (also known as economic rights) which require the provision of such necessities as education, paid holidays and protections against severe poverty and starvation; and (f) Group rights.
} 
known as the European Convention on Human Rights ${ }^{14}$ (hereafter, simply Convention), although economic rights are added by later protocols ${ }^{15}$ : (1) on the right to property, education and free elections, civil imprisonment; (4) on freedom of movement and expulsion; (6) on the death penalty, prohibiting it except in war times; (7) on expulsion, criminal appeals, compensation, double jeopardy and spousal equity; (12) on discrimination; and (13) on the death penalty. Moreover, the 'economic rights' of workers are specifically catered for by the International Labour Organisation (ILO) ${ }^{16}$ and since ILO is a specialised agency of the UN to which all 192 UN member nations belong, it follows that all UN members are covered by its mandate.

\section{Regional Integration and Human/Economic Rights}

I have scanned the treaties establishing the major schemes of economic integration ${ }^{17}$ and found no mention of economic rights or of human rights, in any of them except in the case of the European Union (EU) where they are stated in the Charter of Fundamental Rights of the European Union. ${ }^{18}$ Although the Constitutive Act of the African Union ${ }^{19}$ is 'DETERMINED to promote and protect human and peoples' rights, consolidate democratic institutions and culture, and to ensure good governance and the rule of law ${ }^{20}$, not only is it silent on how it would carry out the

\footnotetext{
${ }^{14}$ See, inter alia, Council of Europe (2007) and Wikipedia (2007).

${ }^{15}$ See, Whelan and Donnelly (2007, pp. 942-4) for a detailed explanation.

${ }^{16}$ See International Labour Organisation (2007). See, Whelan and Donnelly (2007, pp. 940-2) for an excellent and detailed treatment of the relationship between the rights specified in the ILO conventions, the Universal Declaration and the two Covenants.

${ }^{17}$ The Asia-Pacific Economic Cooperation (APEC) forum (APEC Secretariat, 1993-2007), Association of South East Asian Nations (ASEAN, 2007a), Caribbean Community and Common Market (CARICOM; see Foreign Trade Information System, 2007e), Central American Common Market (CACM; see Foreign Trade Information System, 2007a), European Free Trade Association (EFTA Secretariat, 2006), European Union (EU Commission, 2004), North American Free Trade Agreement (NAFTA; see Foreign Trade Information System, 2007d), Latin American Integration Association (ALADI; see Foreign Trade Information System, 2007b), and Southern Cone Common Market (MERCUSOR; Foreign Trade Information System, 2007c).

${ }^{18}$ See European Commission (2007b) and footnote 21 for a summary of the Charter.

${ }^{19}$ The AU was established in 2001 by 53 of the 54 African nations, but its origins go back to the mid1990s when the Libyan head of state, Muammar al-Qaddafi, talked his OAU colleagues into signing the Sirte Declaration on 9 September 1999, followed by the adoption of the Constitutive Act of the African Union in Lomé in 2000, then the plan for its implementation in Lusaka in 2001 and its launch in Durban on 9 July 2002 (see El-Agraa, 2004 for a detailed exposition). Morocco refused to join the AU because it opposes membership of Western Sahara as the Sahrawi Arab Democratic Republic, but I have argued elsewhere (El-Agraa, 2007) that Morocco would like to stay clear of Africa so as to promote itself as a potential EU nation.

${ }^{20}$ African Union (2002), p. 2.
} 
'promotion', let alone the 'protection', but also, and vitally, the African Union is an amalgamation of the African Economic Community (AEC), which is a regional bloc, and the Organisation of African Unity (OAU), which is a political association, and this item does not appear in the AEC treaty. Moreover, although the OAU adopted its African Charter on Human and Peoples' Rights ${ }^{21}$ on 27 June 1981, entered into force in 1986, this simply reiterates what is in the Universal Declaration and on economic rights has items on only the right to property (Article 14); work and equal pay for equal work (Article 15); and free disposal of wealth and natural resources (Article 21).

ASEAN is in the same boat as the AU. Article 1.7 of the ASEAN Charter ${ }^{22}$, adopted on 20 October $2007^{23}$, states that the purpose of ASEAN is: 'To strengthen democracy, enhance good governance and the rule of law, and to promote and protect human rights and fundamental freedoms, with due regard to the rights and responsibilities of the Member States of ASEAN' (italics added). This is reiterated in Article 2.2(i) which calls for 'respect of fundamental freedoms, the promotion and protection of human rights, and the promotion of social justice'. This commitment is immediately compromised in Article 2.2(a,e) which stresses the 'independence' and 'sovereignty' of the member states and 'non-interference in the[ir] internal affairs'. This is reinforced in Article 14, relating to the establishment of an 'ASEAN human rights body' to 'operate in accordance with the terms of reference to be determined by the ASEAN Foreign Ministers Meeting' (italics added). Moreover, Article 20.4 stipulates that 'In the case of a serious breach of the Charter or non-compliance, the matter shall be referred to the ASEAN Summit for decision' (italics added). Since 'As a basic principle, decision-making in ASEAN shall be based on consultation and consensus' (Article 20.1), any serious analyst would argue that "it is difficult to envision a "human rights body" with any teeth or credibility ${ }^{24}$, given that at such summits the culprit will have a veto over any punishment. Indeed, realising the futility of this, the 'eminent persons' group commissioned by ASEAN to make recommendations on the charter, had concluded that ASEAN must provide for sanctions, including possible expulsion, against members who flout the bloc's principles and ignore its rulings, but

\footnotetext{
${ }^{21}$ See Organisation of African Unity (1981). Donnelly calls it 'the most heterodox regional treaty' on the subject (Donnelly, 2003, p. 96).

${ }^{22}$ See, the Association of Southeast Asian Nations (2007b).

${ }^{23}$ Singapore became the first to deposit its instruments of ratification, on 7 January 2008.

${ }^{24}$ See, inter alia, Cossa (2007) and The Economist (2007, pp. 35-6).
} 
obviously to no avail. They also proposed deciding some issues by voting, instead of only by consensus; likewise cast aside. Moreover, in a 2005 study by the Institute of Southeast Asian Studies, Singapore, Severino had suggested that under such circumstances, decisions should be based on unanimity 'but without the participation of the member-state that is the subject of the proposed...sanction" ${ }^{25}$; likewise ignored. In other words, everything concerning human rights is not only left hanging in the air, but is also conditional on the ratification of the Charter, which, despite the ratification by Singapore in January $2008^{26}$, is by no means guaranteed, given what Philippine President Gloria Macapagal Arroyo said on 6 December 2007: 'The release from house arrest of Aung San Suu Kyi, Burma's opposition leader and democracy campaigner, will be the "number one benchmark" for the Philippines in deciding whether to ratify the new charter"27. What is pertinent is that with regard to economic rights, I can detect only one item that comes close to them: Article 1.7 intends 'To alleviate poverty and narrow the development gap within ASEAN through mutual assistance and cooperation' without specifying what form the assistance should take, the nature of the cooperation or, vitally, how this should be enforced.

The fact that no scheme of regional integration other than the EU has economic rights enshrined is most true in the case of the Americas and the Middle East. ${ }^{28}$ With regard to the Americas, all the states in this hemisphere belong to the 1948 American Declaration of the Rights and Duties of Man, which obviously predates the Universal Declaration, but its list more or less matches it. They also belong to the 1969 American Convention on Human Rights, which recognises personal, legal, civil and political rights, plus the right to property; and the 1988, coming into force in 1999, Protocol of San Salvador, which caters for economic, social and cultural rights. Yet none of the three has anything to do with regional integration since they are not incorporated into their regional integration treaties. As to the Middle East, the Arab League established a Permanent Arab Commission on Human Rights in 1968, but it is inactive, except for publicizing the human rights situation in the Israeli-occupied territories, and the Arab Charter of Human Rights, drafted in 1971 but not adopted by the Council of the Arab League until 1994,

\footnotetext{
${ }^{25}$ See, Severino (2005, p. 27).

${ }^{26}$ The instruments of ratification were deposited by Singapore with the ASEAN Secretariat on 7 January 2008.

${ }^{27}$ Quotation from The Financial Times (2007).

${ }^{28}$ See, Donnelly (2003, pp. 143-5) for a somewhat detailed exposition.
} 
fares likewise. And, again, these have nothing to do with regional integration.

Thus a serious consideration of economic rights has to be confined to the case of the EU. It is in this sense that economic integration, as a field of economic inquiry, has nothing to do with economic rights: economic rights are peculiar/particular to the EU and the EU happens to be a scheme of economic integration, albeit the most significant and influential of such schemes. ${ }^{29}$ Indeed, the EU itself admits that there is nothing novel about the incorporation of economic and human rights into EU treaties since the member nations have already committed themselves to all their essential elements as members of the UN, the Convention, the ILO charter, etc. In the words of the EU:

[On 3/4 June 1999] the Cologne European Council concluded that the fundamental rights applicable at the EU level should be consolidated in a charter, to give them greater visibility. The Heads of State or Government believed that the charter should contain the general principles set out in the Council of European Convention of 1950 and those derived from the constitutional traditions common to the Member States, as well as the fundamental rights that apply only to the Union's citizens and the economic and social rights contained in the European Social Charter and the Community Charter of the Fundamental Social Rights of Workers. It would also reflect the principles derived from the case law of the Court of Justice and the European Court of Human Rights ${ }^{30}$ (italics added).

This reiterates what was stated in the aborted Constitutional Treaty:

For the first time a single document brings together all of the rights previously to be found in a variety of legislative instruments, such as national laws and international conventions from the Council of Europe, the United Nations and the International Labour Organisation. By making fundamental rights and freedoms clearer and more visible, the Charter helps to develop the concept of citizenship of the European Union and to create an area of freedom, security and justice (as stated in the preamble). The Charter enhances legal security as regards the protection of fundamental rights, where in the past such protection was guaranteed only by the case law of the Court of Justice and Article 6 of the Treaty on European Union (italics added).

${ }^{29}$ See El-Agraa (2007, pp. 4-6) for information supporting both counts.

${ }^{30}$ See the EU website. 
In other words, the EU is simply trying to incorporate its member nations' international commitments, plus some of their/its own, into the legal system of their regional association. This incorporation astonishes those analysts who believe that the EU will never become a single state: a bloc of states does not need to have what is reserved for separate sovereign nations. It, however, elates those who share the EU founding fathers' dream of the creation, through the backdoor, of a 'United States of Europe'.

\section{The EU's Economic Rights}

As mentioned above, the EU's economic rights are stated in Charter of Fundamental Rights of the European Union. The Charter is now part of the 2007 Lisbon Treaty, popularly known as the 'reform treaty', so one would be expected to examine them within its context. However, the treaty itself refers one to the Charter ${ }^{31}$ for economic rights in particular and human rights in general, adding

\footnotetext{
${ }^{31}$ Article 6.1 of the Lisbon Treaty states that 'The Union recognises the rights and principles set out in the Charter of Fundamental Rights of the European Union of 7 December 2000, as adapted at Strasbourg, on 12 December 2007, which shall have the same legal value as the Treaties'.

${ }^{32}$ The Charter contains a preamble and 54 Articles, grouped in seven chapters:

- Chapter I: Dignity (human dignity, the right to life, the right to the integrity of the person, prohibition of torture and inhuman or degrading treatment or punishment, prohibition of slavery and forced labour); - Chapter II: Freedoms (the right to liberty and security, respect for private and family life, protection of personal data, the right to marry and found a family, freedom of thought, conscience and religion, freedom of expression and information, freedom of assembly and association, freedom of the arts and sciences, the right to education, freedom to choose an occupation and the right to engage in work, freedom to conduct a business, the right to property, the right to asylum, protection in the event of removal, expulsion or extradition);

- Chapter III: Equality (equality before the law, non-discrimination, cultural, religious and linguistic diversity, equality between men and women, the rights of the child, the rights of the elderly, integration of persons with disabilities);

- Chapter IV: Solidarity (workers' right to information and consultation within the undertaking, the right of collective bargaining and action, the right of access to placement services, protection in the event of unjustified dismissal, fair and just working conditions, prohibition of child labour and protection of young people at work, family and professional life, social security and social assistance, health care, access to services of general economic interest, environmental protection, consumer protection);

- Chapter V: Citizens' rights (the right to vote and stand as a candidate at elections to the European Parliament, the right to vote and stand as a candidate at municipal elections, the right to good administration, the right of access to documents, the ombudsman, the right to petition, freedom of movement and residence, diplomatic and consular protection);

- Chapter VI: Justice (the right to an effective remedy and a fair trial, the presumption of innocence and the right of defence, principles of legality and proportionality of criminal offences and penalties, the right not to be tried or punished twice in criminal proceedings for the same criminal offence);

- Chapter VII: General provisions
} 
only certain provisos and protocols; hence one has to be concerned with what is in the Charter. The need to refer to the Charter is reinforced when one realises that the Lisbon Treaty has to be ratified before it can enter into force in January 2009 when ratification is by no means fully guaranteed, i.e. the Charter is here to stay while the Lisbon Treaty is yet to become EU law. Note however that what is particularly significant is that both Poland and the UK have opt-outs of the economic rights, stated in both the treaty where they are fully set out in the Protocols, and Charter. What is vital is that since the enactment of economic rights does not extend to the entire EU membership, it follows that they have nothing to do with the EU as a scheme of regional integration.

Of the particular concern of economic rights in the Charter ${ }^{32}$ are articles 15-19 and 27-38:

Article 15 Freedom to choose an occupation and right to engage in work

1. Everyone has the right to engage in work and to pursue a freely chosen or accepted occupation.

2. Every citizen of the Union has the freedom to seek employment, to work, to exercise the right of establishment and to provide services in any Member State.

3. Nationals of third countries who are authorised to work in the territories of the Member States are entitled to working conditions equivalent to those of citizens of the Union.

Article 16 Freedom to conduct a business

The freedom to conduct a business in accordance with Union law and national laws and practices is recognised.

Article 17 Right to property

1. Everyone has the right to own, use, dispose of and bequeath his or her lawfully acquired possessions. No one may be deprived of his or her possessions, except in the public interest and in the cases and under the conditions provided for by law, subject to fair compensation being paid in good time for their loss. The use of property may be regulated by law in so far as is necessary for the general interest.

2. Intellectual property shall be protected.

Article 27 Workers' right to information and consultation within the undertaking

Workers or their representatives must, at the appropriate levels, be 
guaranteed information and consultation in good time in the cases and under the conditions provided for by Union law and national laws and practices.

Article 28 Right of collective bargaining and action

Workers and employers, or their respective organisations, have, in accordance with Union law and national laws and practices, the right to negotiate and conclude collective agreements at the appropriate levels and, in cases of conflicts of interest, to take collective action to defend their interests, including strike action.

Article 29 Right of access to placement services

Everyone has the right of access to a free placement service.

Article 30 Protection in the event of unjustified dismissal

Every worker has the right to protection against unjustified dismissal, in accordance with Union law and national laws and practices.

Article 31 Fair and just working conditions

1. Every worker has the right to working conditions which respect his or her health, safety and dignity.

2. Every worker has the right to limitation of maximum working hours, to daily and weekly rest periods and to an annual period of paid leave.

Article 32 Prohibition of child labour and protection of young people at work

The employment of children is prohibited. The minimum age of admission to employment may not be lower than the minimum school-leaving age, without prejudice to such rules as may be more favourable to young people and except for limited derogations.

Young people admitted to work must have working conditions appropriate to their age and be protected against economic exploitation and any work likely to harm their safety, health or physical, mental, moral or social development or to interfere with their education.

Article 33 Family and professional life

1. The family shall enjoy legal, economic and social protection.

2. To reconcile family and professional life, everyone shall have the right to protection from dismissal for a reason connected with maternity and the right to paid maternity leave and to parental leave following the birth or adoption of a child. 
Article 34 Social security and social assistance

1. The Union recognises and respects the entitlement to social security benefits and social services providing protection in cases such as maternity, illness, industrial accidents, dependency or old age, and in the case of loss of employment, in accordance with the rules laid down by Union law and national laws and practices.

2. Everyone residing and moving legally within the European Union is entitled to social security benefits and social advantages in accordance with Union law and national laws and practices.

3. In order to combat social exclusion and poverty, the Union recognises and respects the right to social and housing assistance so as to ensure a decent existence for all those who lack sufficient resources, in accordance with the rules laid down by Union law and national laws and practices.

Article 35 Health care

Everyone has the right of access to preventive health care and the right to benefit from medical treatment under the conditions established by national laws and practices. A high level of human health protection shall be ensured in the definition and implementation of all the Union's policies and activities.

Article 36 Access to services of general economic interest

The Union recognises and respects access to services of general economic interest as provided for in national laws and practices, in accordance with the Treaties, in order to promote the social and territorial cohesion of the Union.

Article 37 Environmental protection

A high level of environmental protection and the improvement of the quality of the environment must be integrated into the policies of the Union and ensured in accordance with the principle of sustainable development.

Article 38 Consumer protection

Union policies shall ensure a high level of consumer protection.

I do not intend to discuss the merits and demerits of these items here since this has been done extensively in the literature. All I need to tackle is the question of why they have proved to be controversial: as mentioned, both Poland and the United Kingdom have opt-outs stated in Protocols to the Treaty. The answer is that 
especially the UK finds it difficult to extend a legal status to the items related to minimum wages, working hours and aggressive trade union activities (Articles 28 and 31.2 highlighted in bold italics). This is because memories are still alive regarding how the miners' trade unions held the country to ransom during the 1970s, a holding which was not released until the Margret Thatcher Conservative government set out to destroy the trade unions. Ironically, this destruction was continued by the Labour Party, leading to the ten years ending in 2007 of Tony Blair as prime minister. That is however not as important as the UK fear of setting minimum wages at a legally binding high level. Doing so would increase costs, leading to higher unemployment and undermining the admirable economic growth achieved over the past decade and a half. Combining the two ills together is therefore frightening; hence the UK's stance. One must stress however that it is the 'legalisation' that worries the UK, not the 'spirit' since the UK is a signatory to all the mentioned pertinent international and European treaties.

There is also a 'fundamental' rationale in that not all agree that economic rights are human rights. In my opinion as a non-expert on human rights, I believe the best exposition of this disagreement is given by Donnelly and Whelan and Donnelly ${ }^{33}$, quoted here fully but with slight adaptation:

The Universal Declaration model treats internationally recognised human rights holistically, as an indivisible structure in which the value of each right is significantly augmented by the presence of many others. As Article 5 of the 1993 Vienna Declaration puts it. 'All human rights are universal, indivisible and interdependent and interrelated'.

During the Cold War, this doctrine was regularly challenged. In particular, the relationship between civil and political rights and economic, social and cultural rights was a matter of intense and lively,

\footnotetext{
${ }^{33}$ See, Donnelly (2003, pp. 27-30) and Whelan and Donnelly (2007).

${ }^{34}$ For example, as of 22 October 2001, only ten countries were party to just one of the Covenants (and five of those have signed but not yet ratified the other). 140 states were parties to both (and an additional four had signed but not yet ratified both). http://www.unhchr.ch/pdf/report.pdf Needless to add, today most nations have signed and ratified the Covenants.

${ }^{35}$ The continuing policy relevance of the debate is suggested by a recent issue of The Economist (18-24 August 2001), which devotes its cover, the principal leader and a 3-page Special Report to the status of economic and social rights. Given the magazine's position on the right of the European political spectrum, it is of significance that the leader accepts (with only moderate reluctance) the reality of economic and social human rights although it does question the practicality of implementing many and claims that 'the moral imperative to stop poverty or disease is...not as convincing as the moral imperative to stop torture' (p. 19).
} 
although not particularly productive or illuminating, controversy. Commentators and leaders in all Soviet bloc and most Third World countries regularly disparaged most civil and political rights. Conversely, many Western (especially Anglo-American) conservatives and philosophers - but, significantly, only the government of the United States - disparaged most economic and social rights.

Such debates have largely receded from international discussions ${ }^{34}$, but their legacy remains in the persistence of the categories of civil and political and economic, social and cultural rights. We should also note that in some Western circles a lingering suspicion of economic and social rights persists. ${ }^{35}$ This is particularly true in the US, where scepticism persists across much of the mainstream political spectrum. 1. The status of economic and social rights

In international discussions it has become almost a reflex to talk of 'civil and political rights' and 'economic, social and cultural rights'. Although I too occasionally use these categories, they are seriously misleading. A dichotomous division of any complex reality is likely to be crude and easily (mis)read to suggest that the two categories are antithetical. This is especially true because the dichotomy between civil and political rights and economic, social and cultural rights was born of political controversy, first in working-class political struggles in the $19^{\text {th }}$ and early $20^{\text {th }}$ centuries and then in the Cold War ideological rivalry. But the argument against economic and social rights has also been philosophical, not merely political or polemical. Maurice Cranston (1964) offers the most widely cited argument that whereas traditional civil and political rights to life, liberty and property are 'universal, paramount, categorical moral rights' (1964, p. 40), economic and social rights 'belong to a different logical category' (1964, p. 54), i.e. they are not truly human rights ${ }^{36}$ (italics added). As Chapter 1 suggests, I accept universality and paramountcy as central indicators of rights that might appropriately be considered human rights. But Cranston is simply wrong that internationally recognised economic, social and cultural rights fail to meet these tests.

\footnotetext{
${ }^{36}$ Cranston goes so far as to claim that such rights ' $[\mathrm{do}]$ not make sense' and suggests that claims of such rights probably are not even 'intelligible' (pp. 65 and 69).
} 
Cranston notes that the right to work, like many other economic and social rights, refers directly to a particular class of people rather than all human beings (1964, p. 67). Many civil and political rights, though, also fail such a test of universality. For example, only citizens who have attained a certain age and completed any necessary formalities of registration have the right to vote.

As for (lack of) paramountcy, Cranston singles out the right to periodic holidays with pay (1973, pp. 66-7). But is such a right any less important than, say, the right of juveniles to separate prison facilities, a right recognised in the International Covenant on Civil and Political Rights? Questions concerning paramountcy arise in both cases because the right in question has been specified in rather detailed terms... In the case of paid holidays, the full right recognised is a right to 'rest, leisure, and reasonable limitation of working hours and periodic holidays with pay'. Denial of this right would indeed be a serious affront to human dignity; it was, for example, one of the most oppressive features of unregulated $19^{\text {th }}$ century capitalism.

In any case the right to periodic holidays with pay is hardly the typical economic and social right. For example, the right to work is arguably as important as most basic civil and political rights; the psychological, physical and moral effects of prolonged enforced unemployment may be as severe as those associated with denial of, say, freedom of speech. A right to education may be as essential to life of dignity as freedom of speech or religion. (Economic and social) rights to food and health care may be as essential for protecting life as the (civil or political) right to life.

Cranston's appeal to (im)practicality is more complex. "Political rights" can be readily secured by legislation. ${ }^{37}$ The economic and social rights can rarely, if ever, be secured by legislation alone' (1964, p. 37; italics added). In fact, however, no right can be readily realised through legislation alone. Unless legislation is backed by enforcement, the right is likely to be legally and politically insecure.

'There is nothing essentially difficult about transforming political and

\footnotetext{
${ }^{37} \mathrm{He}$ even claims that civil and political rights 'generally...can be secured by fairly simple legislation' (1973, p. 66).
} 
civil rights into positive rights', whereas realising economic and social rights is 'utterly impossible' in most countries (1973, p. 66; italics added). 'To guarantee civil and political rights is relatively cheap, whereas to guarantee economic and social rights is potentially enormously costly' (The Economist 2001, p. 66; italics added). Both sides of such claims are problematic.

There are in fact severe impediments to establishing an effective positive right to, say, freedom of speech, press or assembly in North Korea, Liberia, Cuba, China or Burma. Only in particular kinds of political circumstances - for example, where there has already been considerable progress in implementing many internationally recognised human rights - are civil and political rights likely to be systematically easier to implement. Even then, the differences are more matters of degree than kind. And they vary considerably from right to right and with time and place.

If we insist on the standards of, say, Sweden, it may not be false to say that realising most economic and social rights is 'impossible' in most countries. But Northern European standards for civil and political rights would be nearly as 'impossible'. Resource shortages, as even the most conservative international financial institutions have come to understand, usually are largely attributable to poor governance. The problems to which Cranston points are matters of political economy, not natural scarcity.

Because rights impose correlative duties and, as the old moral maxim puts it, 'ought implies can' - no one has an obligation to attempt what is truly impossible - Cranston argues that it is logically incoherent to hold that economic and social 'rights' are anything more than utopian aspirations (1973, p. 68). The 'can' in 'ought implies can', however, refers to physical impossibility; unless it is physically impossible, one may still be obliged to try to do something that proves to be 'impossible'. The impediments to implementing most economic and social rights, however, are political. For example, there is more than

\footnotetext{
${ }^{38}$ In fact, over the past half century famines have occurred only in places where there was enough food for everyone within the borders of the famine-stricken country (Sen, 1981; 1990).

${ }^{39}$ Whelan and Donnelly (2007, p. 29).
} 
enough food in the world to feed everyone; widespread hunger and malnutrition exist not because of a physical shortage but because of political decisions about its distribution. ${ }^{38}$

This leaves Cranston with little more than an argument that civil and political rights are relatively easy to implement. Hugo Adam Bedau advances a similar 'argument from indifference to economic contingencies' (1979, pp. 36-7). Even granting such empirically dubious claims, I cannot see why ease or expense of implementation should have any conceptual or moral significance. It seems odd to me to suggest that something is a real human right only if it is relatively easy to implement. Ease of implementation is certainly irrelevant to determining moral paramountcy.

I believe this admirably clarifies the UK's position in that it disagrees with Donnelly's complete demolition of Cranston's position especially with regard to the highlighted items. To paraphrase the famous Clinton first presidential campaign slogan, 'it's the costs stupid'; in other words, even if the UK fully supported Donnelly's stance, as an argued logical construct, it is the cost implications that would arise from legalising the economic rights that is the main concern since legal enactment would deter flexibility in using macroeconomic policy tools for finetuning the economy. Indeed, as Whelan and Donnelly clearly point out, the birth of the Economic, Social and Cultural Covenant was due to the realisation that 'states during the 1950s and 1960s had considerable capability to create subjective civil and political rights...in national law for all individuals, whereas most states lacked the combination of will and resources needed to provide comparable legal guarantees for most economic and social rights' (italics added). ${ }^{39}$ Obviously, Poland and the UK believe that today's conditions are not much different from those of five decades ago.

Before closing this section, I must mention an interesting observation kindly drawn to my attention by Professor Amy Verdun. She states that these so-called 'economic rights', either those already contained in all the EU treaties, or the Charter when it becomes part of the Lisbon Treaty, are really legal rights that happen to have an 'economic' focus. As such, it is the focus on 'rights' that makes the EU particular. Indeed, the EU has a particular way in which it operates which is

\footnotetext{
${ }^{40}$ See Chalmers' contribution on 'the legal dimension in EU integration' to the $6 \mathrm{t}^{\mathrm{h}}$ and $7^{\text {th }}$ editions of ElAgraa (2007) and of Chalmers and Haasbeek's to the 8th edition.

${ }^{41}$ Directive 75/117/EEC, Official Journal of the European Communities, Legal, 45/75.
} 
directly related to the fact that its governance structure is based on treaties (legal bases). This legal dimension has indeed been emphasised by Chalmers and Chalmers/Haasbeek ${ }^{40}$ and I shall return to it in the final section of this paper where I use two well-known cases to demonstrate its importance. She adds that it is difficult to conceptualise how the EU would have developed so far if it were not for a prominent role for the legal basis; hence a 'rights-based' model of governance. An alternative could be more political integration, but it is very difficult to move from a 'free trade area' to political integration without making steps, and the EU model fits perfectly into this conception, much to the mentioned dislike of those who believe that the EU should stay away from political integration.

\section{The EU Way of Promoting Economic Rights}

The above has hopefully clearly demonstrated that economic rights are peculiar/ particular to the EU. They are not conditional on the formation of regional integration schemes; hence are not the concern of WTO. In this final section I want to provide you with particular cases where the EU as a regional integration scheme has been able to promote economic rights when the individual member states had miserably failed to do so. Two (due to space limitations) of these cases have arisen from judgements by the European Court of Justice (ECJ) and the third is a condition that the EU insists must be met by countries aspiring to join the EU.

The first is the 1975 Sabena air hostess case. A Sabena airline hostess had tried to get the Belgian courts to rule in favour of her getting equal pay and service conditions relative to her male colleagues but to no avail. The case was then lodged with the ECJ for consideration under Article 119 EC on equal pay and the ECJ ruled that the article was intended to be taken seriously and properly applied. This enabled the European Commission to produce a directive ${ }^{41}$ on equal pay in 1975, which set the way for the promotion of equal treatment of the sexes; promotion because of the problems regarding the definition of 'equal' when most women do

\footnotetext{
${ }^{42}$ Case 120/78 Rewe v Bundesmonopolverwaltung für Branntwein [1979] ECR 649. The case was brought before the ECJ because the West German company Rewe Zentral AG wanted to import Creme de Cassis, a liqueur otherwise known as Cassis de Dijon, into West Germany and found that it could not do so because it did not have enough alcohol to be deemed a liqueur by West German standards.

${ }^{43}$ Official Journal of the European Communities, C256/2, 1980.

${ }^{44}$ Official Journal of the European Communities, C136/1, 1985.

${ }^{45}$ See EU Commission (1993), p. 13.
} 
different work from men. It is doubtful if the progress achieved in this area would have been possible given the national hurdles against equality in this respect.

The second is the 1978 Cassis de Dijon ${ }^{42}$ judgement. The ECJ ruled that Article $28 \mathrm{EC}$ required member states, in the absence of a compelling public interest, to grant market access to products lawfully marketed or manufactured in another member state. The European Commission exploited this judgement to provide the basis for its new approach to harmonisation which lay at the heart of the 1992 Single European Market programme. The Commission argued that the judgement entrenched the principle of mutual recognition, whereby a member state should accept that the regulatory requirements of the member state where the good (or service) was produced were, in principle, equivalent to its own. ${ }^{43}$ This alleviated the need for total harmonisation of regulatory requirements by the Community. Instead, an approach based on mutual recognition transformed the role of the EC legislature into that of providing minimum guarantees. It would harmonise only those essential health and safety standards that were necessary to prevent member states claiming that trade infringed some essential public interest. ${ }^{44}$ To put it in a nutshell, without this judgement, it would have been practically impossible to initiate the Single Market, which is considered the most important achievement of the EU to date, given the EU member nations' aversion to total harmonisation.

The condition is the Copenhagen 21-22 June 1993 criterion $^{45}$ that EU

Membership requires that the candidate country has achieved stability of institutions guaranteeing democracy, the rule of law, human rights and respect for the protection of minorities, the existence of a functioning market economy as well as the capacity to cope with competitive pressure and market forces within the Union. Membership presupposes the candidate's ability to take on obligations of membership including adherence to the aims of political, economic and monetary union (italics added).

The point to highlight is the requirement of a functioning competitive market economy; not specifically EMU membership, given the opt-outs granted to Denmark and the UK.

\section{Conclusion}

My conclusion is that stated at the start: economic rights have nothing to do with regional integration. The EU happens to be the only regional integration scheme 
that is trying the give economic rights a legally-binding basis, but this will not happen fully until the Lisbon Treaty has been ratified. Yet even then, the enactment would not be embracive as long as Poland and the UK continue to exercise their rights to opt-out; thus rendering the term regional integration somewhat meaningless within this context. This, however should not distract from the fact that the EU has been able to make progress with and achieve the promotion of human rights in areas where single member state efforts have been to no avail; feats that would otherwise not have been possible without the creation of a single European state.

This conclusion has pertinent relevance to ASEAN since it is the only other scheme of regional integration that has incorporated human rights in its recently adopted Charter. However, I have argued that everything concerning human rights in ASEAN is not only left hanging in the air, but is also conditional on the ratification of the Charter, which, despite the ratification by Singapore in January 2008, is by no means guaranteed, given Philippine President Gloria Macapagal Arroyo proviso that the release from house arrest of Aung San Suu Kyi, Burma's opposition leader and democracy campaigner, will be the 'number one benchmark' for the Philippines in deciding whether to ratify the new charter'. What is more pertinent is that with regard to economic rights, one can detect only one item that comes close to them: Article 1.7 intends 'To alleviate poverty and narrow the development gap within ASEAN through mutual assistance and cooperation' without specifying what form the assistance should take, the nature of the cooperation or, vitally, how this should be enforced.

Finally, lest I be misunderstood, I have not argued here that regional integration should have nothing to do with economic or for that matter human rights. All I have tried to point out is that the rules presently governing regional integration are silent on them; hence if it is felt that economic/human rights should be incorporated into these rules, then that would be fine.

\section{Acknowledgements}

Without in any way implicating, I am extremely grateful to Dr Amy Verdun, Jean Monnet Chair in European Integration Studies and Director of the Jean Monnet Centre of Excellence, University of Victoria, and Dr Jack Donnelley,

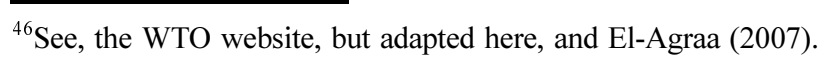


Andrew Mellon Professor at the Graduate School of International Studies, University of Denver, for their helpful comments and suggestions on an earlier draft of this paper.

Received 13 March 2008, Revised 28 July 2009, Accepted 30 July 2009

\section{Appendix}

\section{1: WTO's Article XXIV ${ }^{46}$}

Territorial application - frontier traffic - customs unions and free trade areas

1. The provisions of this Agreement shall apply to the metropolitan customs territories of the contracting parties and to any other customs territories in respect of which this Agreement has been accepted under Article XXVI or is being applied under Article XXXIII or pursuant to the Protocol of Provisional Application. Each such customs territory shall, exclusively for the purposes of the territorial application of this Agreement, be treated as though it were a contracting party; provided that the provisions of this paragraph shall not be construed to create any rights or obligations as between two or more customs territories in respect of which this Agreement has been accepted under Article XXVI or is being applied under Article XXXIII or pursuant to the Protocol of Provisional Application by a single contracting party.

2. For the purposes of this Agreement a customs territory shall be understood to mean any territory with respect to which separate tariffs or other regulations of commerce are maintained for a substantial part of the trade of such territory with other territories.

3. The provisions of this Agreement shall not be construed to prevent:

(a) advantages accorded by any contracting party to adjacent countries in order to facilitate frontier traffic;

(b) advantages accorded to the trade with the Free Territory of Trieste by countries contiguous to that territory, provided that such advantages are not in conflict with the Treaties of Peace arising out of the Second World War.

4. The contracting parties recognize the desirability of increasing freedom of trade by the development, through voluntary agreements, of closer integration between the economies of the countries parties to such agreements. They also recognize that the purpose of a customs union or of a free-trade area should be to 
facilitate trade between the constituent territories and not to raise barriers to the trade of other contracting parties with such territories.

5. Accordingly, the provisions of this Agreement shall not prevent, as between the territories of contracting parties, the formation of a customs union or of a freetrade area of the adoption of an interim agreement necessary for the formation of a customs union or of a free-trade area; provided that:

(a) with respect to a customs union, or an interim agreement leading to the formation of a customs union, the duties and other regulations of commerce imposed at the institution of any such union or interim agreement in respect of trade with contracting parties not parties to such union or agreement shall not on the whole be higher or more restrictive than the general incidence of the duties and regulations of commerce applicable in the constituent territories prior to the formation of such union or the adoption of such interim agreement, as the case may be;

(b) with respect to a free-trade area, or an interim agreement leading to the formation of a free-trade area, the duties and other regulations of commerce maintained in each of the constituent territories and applicable at the formation of such free-trade area or the adoption of such interim agreement to the trade of contracting parties not included in such area or not parties to such agreement shall not be higher or more restrictive than the corresponding duties and other regulations of commerce existing in the same constituent territories prior to the formation of the free-trade area, or interim agreement, as the case may be; and

(c) any interim agreement referred to in sub-paragraphs (a) and (b) shall include a plan and schedule for the formation of such a customs union or of such a freetrade area within a reasonable length of time.

6. If, in fulfilling the requirements of sub-paragraph 5(a), a contracting party proposes to increase any rate of duty inconsistently with the provisions of Article II, the procedure set forth in Article XXVIII shall apply. In providing for compensatory adjustment, due account shall be taken of the compensation already afforded by the reductions brought about in the corresponding duty of the other constituents of the union.

7. (a) Any contracting party deciding to enter into a customs union or free-trade area, or an interim agreement leading to the formation of such a union or area, shall promptly notify the Contracting Parties and shall make available to them such information regarding the proposed union or area as will enable them to make such reports and recommendations to contracting parties as they may deem appropriate. 
(b) If, after having studied the plan and schedule included in an interim agreement referred to in paragraph 5 in consultation with the parties to that agreement and taking due account of the information made available in accordance with the provisions of sub-paragraph (a), the Contracting Parties find that such agreement is not likely to result in the formation of a customs union or of a freetrade area within the period contemplated by the parties to the agreement or that such period is not a reasonable one, the Contracting Parties shall make recommendations to the parties to the agreement. The parties shall not maintain or put into force, as the case may be, such agreement if they are not prepared to modify it in accordance with these recommendations.

(c) Any substantial change in the plan or schedule referred to in paragraph 5(c) shall be communicated to the Contracting Parties, which may request the contracting parties concerned to consult with them if the change seems likely to jeopardize or delay unduly the formation of the customs union or of the free-trade area.

For the purposes of this Agreement:

(a) A customs union shall be understood to mean the substitution of a single customs territory for two or more customs territories, so that

i. duties and other restrictive regulations of commerce (except, where necessary, those permitted under Articles XI, XII, XIII, XIV, XV and XX) are eliminated with respect to substantially all the trade between the constituent territories of the union or at least with respect to substantially all the trade in products originating in such territories, and,

ii. subject to the provisions of paragraph 9, substantially the same duties and other regulations of commerce are applied by each of the members of the union to the trade territories not included in the union.

(b) A free-trade area shall be understood to mean a group of two or more customs territories in which the duties and other restrictive regulations of commerce (except, where necessary, those permitted under Articles XI, XII, XIII, $\mathrm{XIV}, \mathrm{XV}$ and $\mathrm{XX}$ ) are eliminated on substantially all the trade between the constituent territories in products originating in such territories.

9. The preferences referred to in paragraph 2 of Article I shall not be affected by the formation of a customs union or of a free-trade area but may be eliminated or adjusted by means of negotiations with contracting parties affected. This procedure of negotiations with affected contracting parties shall, in particular, apply to the elimination of preferences required to conform with the provisions of paragraph 
8(a)(i) and paragraph 8(b).

10. The Contracting Parties may by a two-thirds majority approve proposals which do not fully comply with the requirements of paragraphs 5 to 9 inclusive, provided that such proposals lead to the formation of a customs union or a freetrade area in the sense of this Article.

11. Taking into account the exceptional circumstances arising out of the establishment of India and Pakistan as independent States and recognizing the fact that they have long constituted an economic unit, the contracting parties agree that the provisions of this Agreement shall not prevent the two countries from entering into special arrangements with respect to the trade between them, pending the establishment of their mutual trade relations on a definitive basis.

12. Each contracting party shall take such reasonable measures as may be available to it to ensure observance of the provisions of this Agreement by the regional and local governments and authorities within its territory.

\section{References}

African Union (2002), Constitutive Act of the African Union, Abuja, Available at: http:// www.au2002.gov.za/docs/key_oau/au_act.htm.

Asia-Pacific Economic Cooperation (APEC) Secretariat (1993-2007), Leaders' Declaration, Available at (change the year for the appropriate declaration): http:// www.apecsec.org.sg/apec/leaders_declarations/2007.html.

Association of South East Asian Nations (2007a), Treaty of Amity and Cooperation in Southeast Asia. Signed in Indonesia on 24 February 1976, Available at: http:// www.aseansec.org/1217.htm.

Association of South East Asian Nations (2007b), Charter of the Association of Southeast Asian Nations, Signed in Singapore on 20 November 2007.

Bedau, H. A. (1979), "Human Rights and Foreign Assistance Programs", in P. G. Brown and D. Maclean (eds.), Comparative Human Rights, Lexington Books, Lexington, Va.

Cossa, R. (2007), "One (very) Small Step forward for ASEAN", The Japan Times, November 27.

Council of Europe (2007), Convention for the Protection of Human Rights and Fundamental Freedoms as amended by Protocol No. 11, Available at: http:// conventions.coe.int/treaty/en/Treaties/Html/005.htm.

Cranston, M. (1964), What are Human Rights? Basic Books: New York. A $2^{\text {nd }}$ edition was published in 1973 by Taplinger: New York.

Donnelly, J. (2003), Universal Human Rights in Theory and Practice, Cornell University Press: Ithaca and London. $2^{\text {nd }}$ edition of the 1989 book. 
Dreze, J. and Sen, A. (1990), Hunger and Public Action, Clarendon Press: Oxford.

EFTA Secretariat (2006), EFTA Convention (Consolidated Version: 2001), Available at: http://secretariat.efta.int/Web/EFTAConvention/EFTAConventionTexts/.

El-Agraa, Ali M (ed.) (2007), The European Union: Economics and Policies, Cambridge University Press: Cambridge and New York, $8^{\text {th }}$ edition of the Economics of the European Community, 1980.

El-Agraa, Ali M (2004), "The Enigma of African Economic Integration”, Journal of Economic Integration, 19(1), pp. 19-45.

El-Agraa, Ali M (1999), Regional Integration: Experience, Theory and Measurement. Macmillan: Hemel Hempstead; Barnes \& Noble: New York, the Second Edition of International Economic Integration (1982), Macmillan: London; St. Martin's Press: New York).

El-Agraa, Ali M. (1998), International Trade, MacMillan: Hemel Hempstead; St Martin's Press: New York, the Second Edition of The Theory of International Trade (1985), Croom Helm: Beckenham; St. Martin's Press: New York.

El-Agraa, Ali M. (1982), International Economic Integration (Macmillan: London; St. Martin's Press: New York).

El-Agraa, Ali M. and Anthony J. Jones (1981), Theory of Customs Unions (Philip Allan: Oxford; St. Martin's Press: New York).

European Commission (1993), "Copenhagen European Council", Bulletin of the European Communities, 26(6).

European Commission (2000), "Nice Council", Bulletin of the European Union, no. 12.

European Commission (2004), "Provisional Consolidated Draft Treaty Establishing a Constitution for Europe", Conference of the Representatives of the Governments of the Member States, CIG 86/04. Brussels, 25 June, Available at the EU website: http:/ leuropa.eu/.

European Commission (2007a), "Charter of Fundamental Rights of the European Union", Official Journal of the European Union C 303/1; Downloaded, but Adapted, from the EU Website Available at: http://europa.eu/.

European Commission (2007b), Treaty of Lisbon amending the Treaty of European Union and the Treaty establishing the European Community, CIG 14/07; Can Be Downloaded from the EU Website Available at: http://europa.eu/.

European Council of Ministers and Commission (Annual, starting in 1999), EU Annual Report on Human Rights. Brussels; Access at the EU Website Available at: http:// europa.eu/.

Foreign Trade Information System (SICE) (2007a), General Treaty on Central American Integration between Guatemala, El Salvador, Honduras and Nicaragua, Signed at Managua on 13 December 1960.

Foreign Trade Information System (SICE) (2007b), 1980 Treaty of Montevideo: Instrument Establishing the Latin American Integration Association (ALADI). Available at:http://www.sice.oas.org/trade/Montev_tr/indexe.asp.

Foreign Trade Information System (SICE) (2007c), Treaty Establishing a Common Market 
between the Argentine Republic, the Federal Republic of Brazil, the Republic of Paraguay and the Eastern Republic of Uruguay, Available at: http://www.sice.oas.org/ trade/mrcsr/mrcsrtoc.asp.

Foreign Trade Information System (SICE) (2007d), The North American Free Trade Agreement. (NAFTA), Available at: http://www.sice.oas.org/Trade/NAFTA/ naftatce.asp.

Foreign Trade Information System (SICE) (2007e), Treaty Establishing the Caribbean Community and Common Market. (CARICOM), Available at: http://www.sice.oas.org/ trade/ccme/ccmetoc.asp.

International Court of Justice Available at: http://www.icj.-cij.org/.

International Labour Organisation (2007), Constitution of the International Labour Organization, Available at: http://ilo.org/ilolex/english/iloconst.htm.

Organisation of African Unity (1981), African Charter on Human and Peoples' Rights. OAU Doc. CAB/LEG/67/3 rev. 5, 21 I.L.M. 58 (1982).

Organisation of African Unity (1991), Treaty Establishing the African Economic Community, Abuja, Nigeria, $3^{\text {rd }}$ June.

Pickett, J. P. et al. (eds.) (2000), The American Heritage Dictionary of the English Language, $4^{\text {th }}$ edition, Houghton Mifflin Company: Boston.

Sen, A. (1981), Poverty and Famines: an Essay on Entitlement and Deprivation, Oxford University Press: New York.

Severino, R. C. (2005), "Framing the ASEAN Charter: an Ideas Perspective", Chapter 1 in Framing the ASEAN Charter: an Ideas Perspective, Institute of Southeast Asian Studies, Singapore.

The Economist (2007), "South-East Asia's Jamboree: Fifth from the Right Is the PartyPooper", 24 November 2007.

The Financial Times (2007), "South-East Asian Partners: Suu Kyi Freedom Is Test for Asean, Says Macapagal", 7 December 2007.

United Nations (1948), The United Nations Universal Declaration of Human Rights. Adopted by the UN General Assembly resolution 217 A (III) of 10 December 1948. Available at: http://www.unhchr.ch/html/menu6/2/fs2.htm and Can Also be Accessed at http://www.un.org/Overview/rights.html.

United Nations (1966a), The United Nations International Convention on Civil and Political Rights. Available at: http://www.hrweb.org/legal/cpr.htm and Can Also Be Accessed at http://www.un.org/Overview/rights.html.

United Nations (1966b), International Covenant on Economic, Social and Cultural Rights. Available at: http://www.unhchr.ch/html/menu3/b/a_cescr.htm and can also Be Accessed at http://www.un.org/Overview/rights.html.

Whelan, D. J. and Donnelly, J. (2007), "The West, Economic and Social Rights, and the Global Human Rights Regime: Setting the Record Straight", Human Rights Quarterly, vol. 20, pp. 908-949.

Wikipedia (2007), European Convention on Human Rights, Available at: File:// C:IDOCUME 1\ALIEL- 1\LOCALS 1\Templ6203SJ08.htm. 